\title{
Production and Properties of Biosurfactant from Pectinatus cerevisiiphilus CT3 Isolated from Marine Sediments
}

\author{
Chanika SAENGE CHOOKLIN ${ }^{1, *}$ and Atipan SAIMMAI ${ }^{2,3}$ \\ ${ }^{I}$ Faculty of Science and Fisheries Technology, Rajamangala University of Technology Srivijaya, \\ Trang Campus, Trang 90000, Thailand \\ ${ }^{2}$ Faculty of Agricultural Technology, Phuket Rajabhat University, Phuket 83000, Thailand \\ ${ }^{3}$ Andaman Halal Science Center, Phuket Rajabhat University, Phuket 83000, Thailand
}

('Corresponding author's e-mail: chanika.sae@gmail.com)

Received: 14 July 2017, Revised: 16 July 2018, Accepted: 29 August 2018

\begin{abstract}
A marine bacterial isolate, Pectinatus cerevisiiphilus CT3, was able to grow and produce biosurfactant on minimal salts media using glucose and $\mathrm{NaNO}_{3}$ as carbon and nitrogen sources. It was found that cellular growth and biosurfactant production in MSM were greatly affected by the medium components. After $54 \mathrm{~h}$ of cultivation, P. cerevisiiphilus CT3 was able to grow and produce surfactant, reducing the surface tension of the medium to $28.0 \mathrm{mN} / \mathrm{m}$ with a biosurfactant concentration of $3.05 \mathrm{~g} / \mathrm{l}$ and a critical micelle concentration of $10 \mathrm{mg} / \mathrm{l}$. Biosurfactant recovery by chloroform/methanol extraction showed $\mathrm{pH}$ and thermal stability with respect to surface tension reduction. It also showed emulsification activity and a high level of salt concentration. In addition, promising antimicrobial activity was revealed when tested against human pathogenic bacterial and fungal isolates. Based on these results, the isolated biosurfactant from the marine bacteria $P$. cerevisiiphilus CT3 revealed a broad physicochemical stability and has excellent antimicrobial properties, indicating the potential for possible use in various therapeutic and biomedical applications.
\end{abstract}

Keywords: Production, Antimicrobial activity, Biosurfactant, Pectinatus cerevisiiphilus, Marine bacteria

\section{Introduction}

Biosurfactants, or microbial surfactants, are a structurally diverse group of surface-active compounds produced by microorganisms. They consist of hydrophilic and hydrophobic moieties and are able to reduce surface tension and enhance the emulsification of hydrocarbons. Their hydrophilic parts are usually composed of sugars, amino acids, or polar functional groups such as carboxylic acid groups. The hydrophobic part is typically an aliphatic hydrocarbon chain of $\beta$-hydroxy fatty acids. Biosurfactants are primarily classified into glycolipids, lipopeptides, polymeric biosurfactants, fatty acids, and phospholipids [1-3] according to their molecular structures.

Biosurfactants possess a high specificity, including low toxicity, high biodegradability, and effectiveness at extreme temperatures, $\mathrm{pH}$ and salinity. The unique structures of biosurfactants provide specific properties that commercial surfactants usually lack [2,3]. In addition to their utilization in enhanced oil recovery, bioremediation and industrial emulsification, microbial surfactants have been found in recent years to possess several properties of therapeutic and biomedical importance, e.g., antibacterial, antifungal and antiviral properties [4-6]. They also have anti-adhesive effects against several pathogenic microorganisms [7-9]. The present study examines the production, properties and antimicrobial activity of biosurfactant obtained from marine isolates of Pectinatus cerevisiiphilus CT3 
http://wjst.wu.ac.th

(AB685263), which has been preliminarily characterized as a biosurfactant-producing strain as reported in an earlier study [10].

\section{Materials and methods}

\section{Microbial strain}

Pectinatus cerevisiiphilus CT3 (accession number AB685263) was isolated from marine sediment collected from the Palian River in Trang Province in the south of Thailand [10]. The complete 16S rRNA gene sequence from $P$. cerevisiiphilus CT3 showed $100 \%$ homology to Pectinatus cerevisiiphilus CECT4927T (accession number FR870446). P. cerevisiiphilus CT3 was maintained on nutrient agar plates and transferred monthly.

\section{Media and cultivation conditions}

Nutrient broth was used to prepare the inoculum using the following composition in distilled water: $1.0 \mathrm{~g} / 1$ beef extract, $2.0 \mathrm{~g} / 1$ yeast extract, $5.0 \mathrm{~g} / 1$ peptone, and $5.0 \mathrm{~g} / 1 \mathrm{NaCl}$. To make nutrient agar, $15.0 \mathrm{~g}$ of agar was added to the nutrient broth. The strain was cultivated in the nutrient broth overnight at $30^{\circ} \mathrm{C}$. This was used as inoculum at the $5 \%(\mathrm{v} / \mathrm{v})$ level. For biosurfactant production, a mineral salt medium (MSM) with the following composition was utilized: $0.8 \mathrm{~g} / 1 \mathrm{~K}_{2} \mathrm{HPO}_{4}, 0.2 \mathrm{~g} / 1 \mathrm{KH}_{2} \mathrm{PO}_{4}, 0.05 \mathrm{~g} / \mathrm{l} \mathrm{CaCl}, 0.5$ $\mathrm{g} / 1 \mathrm{MgCl}_{2}, 0.01 \mathrm{~g} / 1 \mathrm{FeCl}_{2}$, and $5.0 \mathrm{~g} / 1 \mathrm{NaCl}$ [10]. The $\mathrm{pH}$ of the medium was adjusted to 7.0. Carbon and nitrogen sources were added separately. Cultivation was performed in $250 \mathrm{ml}$ flasks containing $50 \mathrm{ml}$ medium at $30^{\circ} \mathrm{C}$, which were shaken in a rotary shaker at $150 \mathrm{rpm}$ for $48 \mathrm{~h}$.

\section{Medium optimization}

Four main factors were chosen to obtain higher productivity from the biosurfactant: carbon sources, nitrogen sources, carbon/nitrogen ratio, and inoculum concentration. The used carbon sources were glucose, glycerol, molasses, oleic acid, palm oil, soybean oil, stearic acid, and used lubricating oil at a concentration of $5 \mathrm{~g} / \mathrm{l}$. A medium with no carbon source was used as the control assay. The used nitrogen sources were beef extract, monosodium glutamate, $\mathrm{NaNO}_{3},\left(\mathrm{NH}_{4}\right)_{2} \mathrm{SO}_{4}, \mathrm{NH}_{4} \mathrm{Cl}, \mathrm{NH}_{4} \mathrm{NO}_{3}$, peptone, and yeast extract at a concentration of $1 \mathrm{~g} / \mathrm{l}$. A medium with no nitrogen source was used as the control assay. The C:N ratio (with optimized nitrogen source) ranged $1-35$, while the nitrogen source concentration (1 $\mathrm{g} / \mathrm{l})$ was kept constant.

\section{Recovery of biosurfactant}

Acid and ammonium sulphate precipitations and solvent systems were examined for their biosurfactant extraction properties. The four solvent systems were chloroform with methanol (2:1), cold acetone, dichloromethane, and ethanol with ethyl acetates [11-14]. The recovery method showing the highest biosurfactant activity, chloroform with methanol $(2: 1)$, was used to recover biosurfactant from $P$. cerevisiiphilus CT3.

\section{Stability of biosurfactant}

The biosurfactants were dissolved in distilled water at the critical micelle concentration (CMC), and the effects of $\mathrm{pH}$, sodium chloride $(\mathrm{NaCl})$ concentration and temperature on biosurfactant activity were investigated. The effects of $\mathrm{pH}$ were explored by adjusting biosurfactant solutions with $1.0 \mathrm{~N} \mathrm{HCl}$ or $\mathrm{NaOH}$ to obtain a $\mathrm{pH}$ of $2.0-12.0$. The effects of $\mathrm{NaCl}$ concentration were explored by adding $\mathrm{NaCl}$ to the samples to reach final concentrations of $0-21 \%(\mathrm{w} / \mathrm{v})$. For the thermal stability study, biosurfactant solutions were incubated at $4-100{ }^{\circ} \mathrm{C}$ for $1 \mathrm{~h}$ and at $121{ }^{\circ} \mathrm{C}$ for $15 \mathrm{~min}$ and cooled to $25{ }^{\circ} \mathrm{C}$. The remaining activity was then determined. 
http://wjst.wu.ac.th

\section{Biochemical composition of the biosurfactant}

The carbohydrate content of the biosurfactant was determined by the phenol-sulfuric acid method [15] using D-glucose as a standard. Protein content was determined by the method of Lowry et al. [16] using bovine serum albumin as a standard, and the lipid content was estimated by following the procedure of Folch et al. [17].

The chemical composition of the biosurfactant was determined with thin layer chromatography (TLC). The purified biosurfactant was spotted in triplicate on readymade silica gel TLC plates (Merck, Darmstadt, Germany). After the development in $\mathrm{CHCl}_{3}: \mathrm{CH}_{3} \mathrm{OH}: \mathrm{H}_{2} \mathrm{O}(65: 15: 1)$, one of the plates was put into a jar saturated with iodine vapors to detect lipids. Another plate was sprayed with rhodamine B reagent (250 mg rhodamine $\mathrm{B}$ in $100 \mathrm{ml}$ absolute alcohol) and visualized under UV to confirm the presence of lipids. The third plate was sprayed with ninhydrin reagent $(0.2 \%$ ninhydrin solution in acetone) and dried. It was then heated at $120^{\circ} \mathrm{C}$ for $5 \mathrm{~min}$ to detect peptides [18].

\section{Fourier transform infrared spectroscopy}

Fourier transform infrared spectroscopy (FT-IR) is very useful for identifying types of chemical bonds (functional groups) and can therefore be used to analyze the components of an unknown mixture. The obtained biosurfactant $(10 \mathrm{mg}$ ) was ground with $100 \mathrm{mg}$ of potassium bromide and pressed with $7,500 \mathrm{~kg}$ for $30 \mathrm{~s}$ to obtain translucent pellets. Infrared absorption spectra was recorded on a Thermo Nicolet AVATAR 330 FT-IR system with a spectral resolution and wave number accuracy of 4 and 0.01 $\mathrm{cm}^{-1}$, respectively. Each set of measurements consisted of 500 scans, and a potassium bromide pellet was used as a background reference [19].

\section{Antimicrobial activity of the biosurfactant}

The extracted compound was tested for antimicrobial activity using the agar well diffusion method as described by Candan et al. [20]. Briefly, the extract was weighted and dissolved in distilled water at a concentration of $10 \mathrm{mg} / \mathrm{ml}$ and the filter was sterilized by using a $0.2 \mu \mathrm{m}$ membrane filter. Each tested microorganism was suspended in sterile saline and diluted to ca. $10^{6} \mathrm{CFU} / \mathrm{ml}$ for bacteria and $1 \times 1 \mathrm{~cm}^{2}$ for 5-day cultivated fungi $\left(10^{8}\right.$ spore/ml). Microbial suspensions were overlaid onto the surface of BHI agar plates, which were dried for $20 \mathrm{~min}$ at room temperature. The wells ( $5 \mathrm{~mm}$ in diameter) were cut from the agar and $50 \mu \mathrm{l}$ of extracted solution was delivered into them. After an appropriate incubation time (1 and 5 - 7 days for bacteria and fungi, respectively) the clear zone was measured [20].

\section{Analytical methods}

Biomass was determined by the dry cell weight. At different stages of fermentation, samples were mixed in pre-weighted tubes with chilled distilled water and centrifuged at 9,693 $\mathrm{g}$ for $30 \mathrm{~min}$. The biomass obtained was dried overnight at $105^{\circ} \mathrm{C}$ and weighed.

Emulsification activity was performed according to [21]. Briefly, $4 \mathrm{ml}$ of oil or other hydrocarbon was added to $4 \mathrm{ml}$ of aqueous solution of culture supernatant in a screw cap tube and vortexed at high speed for $2 \mathrm{~min}$. The emulsion stability was determined after $24 \mathrm{~h}$ and was calculated by dividing the measured height of the emulsion layer by the mixture's total height. The result was them multiplied by 100.

The surface tension measurement of the culture supernatant was determined in a Model 20 Tensiometer (Fisher Science Instrument Co., Pittsburgh, PA, USA), using the du Nouy ring method [22]. The values reported were the mean of the three measurements. All measurements were made on cultures obtained by centrifuging the cultures at $9,000 \mathrm{~g}$ for $15 \mathrm{~min}$ at $4{ }^{\circ} \mathrm{C}$. The $\mathrm{CMC}$ was determined by plotting the surface tension versus the concentration of biosurfactant in the solution [23].

All experiments were carried out in triple for the calculation of the mean value. Two well-defined synthetic surfactants, SDS and cetrimonium bromide (CTAB), were used as positive controls. Distilled water and an MSM medium were used as negative controls. All of the used chemicals were of analytical grade. Statistical analysis was performed using R software (version 2.13.1). 
http://wjst.wu.ac.th

\section{Results and discussion}

Effect of carbon sources on growth and biosurfactant production of Pectinatus cerevisiiphilus CT3

The literature revealed that the type of carbon source markedly affected the biosurfactant production $[21,24]$. This study began with an examination of the effect of carbon sources on biosurfactant production. $P$. cerevisiiphilus CT3 was grown on all of the tested carbon sources. After $48 \mathrm{~h}$ cultivation, the cultures with glucose and molasses produced 2.55 and $2.41 \mathrm{~g} / 1$ of biomass, respectively. Meanwhile, the maximum biosurfactant production was 0.51 and $0.32 \mathrm{mg} / \mathrm{l}$ for glucose and molasses, respectively. The resulting biosurfactant-containing supernatant had a surface tension reduction of $20.51 \mathrm{mN} / \mathrm{m}$ and achieved an $\mathrm{E}_{24}$ of $36.30 \%$ when glucose was used as a carbon source. Table 1 also shows a clear trend between biomass yield and biosurfactant yield, strongly depending on the carbon source used.

Table 1 Effect of carbon sources on biosurfactant production by Pectinatus cerevisiiphilus CT3, which was cultivated in $250 \mathrm{ml}$ flasks containing $50 \mathrm{ml} \mathrm{MSM}$ medium at $30{ }^{\circ} \mathrm{C}$ in a shaking incubator at 150 rpm for $48 \mathrm{~h}$ (nitrogen source: $\left.1 \%\left(\mathrm{NH}_{4}\right)_{2} \mathrm{SO}_{4}\right)$.

\begin{tabular}{|c|c|c|c|c|}
\hline $\begin{array}{l}\text { Carbon source } \\
(5 \mathrm{~g} / \mathrm{l})\end{array}$ & $\begin{array}{c}\text { Dry cell } \\
\text { weight }(\mathrm{g} / \mathrm{l})^{*}\end{array}$ & $\begin{array}{c}\text { Surface tension } \\
\text { reduction }(\mathrm{mN} / \mathrm{m})\end{array}$ & $\begin{array}{c}\text { Biosurfactant } \\
(\mathrm{g} / \mathrm{l})^{*}\end{array}$ & $\begin{array}{c}\text { Emulsification } \\
\text { activity }^{*}(\%)\end{array}$ \\
\hline No carbon source & $0.12 \pm 0.02^{\mathrm{f}^{* *}}$ & $0^{\mathrm{e}^{* *}}$ & $0^{\mathrm{e}^{* *}}$ & $0^{\mathrm{f**}}$ \\
\hline Glucose & $2.55 \pm 0.21^{\mathrm{a}}$ & $20.51 \pm 2.25^{\mathrm{a}}$ & $0.51 \pm 0.24^{\mathrm{a}}$ & $36.30 \pm 5.20^{\mathrm{a}}$ \\
\hline Glycerol & $2.08 \pm 0.32^{\mathrm{b}}$ & $13.00 \pm 0.50^{\mathrm{c}}$ & $0.20 \pm 0.08^{\mathrm{b}}$ & $25.25 \pm 3.85^{\mathrm{b}}$ \\
\hline Molasses & $2.41 \pm 0.52^{\mathrm{a}}$ & $16.62 \pm 0.62^{b}$ & $0.32 \pm 0.03^{b}$ & $30.17 \pm 2.51^{\mathrm{ab}}$ \\
\hline Oleic acid & $1.80 \pm 0.31^{\mathrm{b}}$ & $10.05 \pm 2.20^{\mathrm{cd}}$ & $0.12 \pm 0.26^{\mathrm{cd}}$ & $15.20 \pm 3.63^{\mathrm{cd}}$ \\
\hline Palm oil & $1.21 \pm 0.15^{\mathrm{c}}$ & $9.25 \pm 1.81^{\mathrm{d}}$ & $0.08 \pm 0.28^{\mathrm{d}}$ & $10.27 \pm 2.58^{\mathrm{e}}$ \\
\hline Soybean oil & $1.41 \pm 0.20^{\mathrm{c}}$ & $12.23 \pm 3.80^{\mathrm{cd}}$ & $0.10 \pm 0.30^{\mathrm{d}}$ & $12.80 \pm 2.35^{\mathrm{de}}$ \\
\hline Stearic acid & $0.94 \pm 0.21^{\mathrm{d}}$ & $13.23 \pm 2.62^{\mathrm{c}}$ & $0.15 \pm 0.15^{b c}$ & $17.38 \pm 2.57^{\mathrm{c}}$ \\
\hline Used lubricating oil & $0.50 \pm 0.20^{\mathrm{e}}$ & $8.65 \pm 0.25^{\mathrm{d}}$ & $0.10 \pm 0.03^{\mathrm{d}}$ & $11.87 \pm 2.00^{\mathrm{e}}$ \\
\hline
\end{tabular}

*Values are given as means \pm SD from triplicate determinations.

${ }^{* *}$ Different superscript letters in the same column indicate significant differences $(p<0.05)$.

Effect of nitrogen sources on growth and biosurfactant production by Pectinatus cerevisiiphilus $\mathrm{CT3}$

With glucose as a carbon source, the choice of nitrogen source affecting the biosurfactant production is depicted in Table 2. After examining the most commonly used organic and inorganic nitrogen sources reported in the literature [25], it was found that $\mathrm{NaNO}_{3}$ was the most efficient nitrogen source for $P$. cerevisiiphilus CT3 to produce biosurfactant, giving a high biosurfactant yield of $2.54 \mathrm{~g} / \mathrm{l}$. This yield is five times the yield obtained from using $\left(\mathrm{NH}_{4}\right)_{2} \mathrm{SO}_{4}$ as the nitrogen source. Moreover, using $\mathrm{NaNO}_{3}$ as the nitrogen source did not only increase the biosurfactant yield but also resulted in an increased biomass and a higher level of surface tension reduction, at $3.25 \mathrm{~g} / 1$ and $30.30 \mathrm{mN} / \mathrm{m}$, respectively. $\mathrm{NaNO}_{3}$ has been previously reported as a suitable nitrogen source for biosurfactant production by Anoxybacillus sp. [26], Wickerhamomyces anomalus PY189 [27], Bacillus flexus [28] and Virgibacillus salariust [29], with the final surface tension of the production yield in the range of 29.5 $42.3 \mathrm{mN} / \mathrm{m}[26,27,29]$. 
http://wjst.wu.ac.th

\section{Effect of carbon to nitrogen $(\mathrm{C}: \mathrm{N})$ ratio on growth and biosurfactant production by Pectinatus cerevisiiphilus CT3}

The C:N ratio has also been known as a vital factor influencing the performance of biosurfactant production [30]. Therefore, the effect of the $\mathrm{C}: \mathrm{N}$ ratio on biosurfactant production was investigated by keeping a constant nitrogen source $\left(1 \mathrm{~g} / \mathrm{l}\right.$ of $\left.\mathrm{NaNO}_{3}\right)$. In terms of carbon, a lower $\mathrm{C}: \mathrm{N}$ ratio resulted in lower levels of cell growth. The lowest $\mathrm{C}: \mathrm{N}$ ratio used $(\mathrm{C}: \mathrm{N}=1)$ resulted in $54 \%$ lower cell growth than the highest C:N ratio used (35:1), as shown in Table 3. The best biosurfactant yield (2.94 g/l) was obtained at a $\mathrm{C}: \mathrm{N}$ ratio of 25 , whereas the productivity tended to decrease as the $\mathrm{C}: \mathrm{N}$ ratio increased from 25 to 35 , especially for $\mathrm{C}: \mathrm{N}$ ratio $>30$. Some reports have stated that biosurfactant production is more efficient under nitrogen limiting conditions [31,32]. The results showed that a possible inhibitory effect on the bacterial metabolism may occur due to a likely nutrient transport deficiency. In addition, the present study also shows that an appropriate amount of nitrogen source is a prerequisite for efficient biosurfactant production with $P$. cerevisiiphilus CT3.

Table 2 Effect of nitrogen source on biosurfactant production by Pectinatus cerevisiiphilus CT3, which were cultivated in $250 \mathrm{ml}$ flask containing $50 \mathrm{ml} \mathrm{MSM}$ medium at $30{ }^{\circ} \mathrm{C}$ in a shaking incubator at 150 rpm for $48 \mathrm{~h}$ (carbon source: $5 \mathrm{~g} / 1$ glucose).

\begin{tabular}{|c|c|c|c|c|}
\hline $\begin{array}{c}\text { Nitrogen source } \\
(1 \mathrm{~g} / \mathrm{l})^{*}\end{array}$ & $\begin{array}{c}\text { Dry cell } \\
\text { weight }(\mathrm{g} / \mathrm{l})\end{array}$ & $\begin{array}{l}\text { Surface tension } \\
\text { reduction }(\mathrm{mN} / \mathrm{m})\end{array}$ & $\begin{array}{c}\text { Biosurfactant } \\
(\mathrm{g} / \mathrm{l})^{*}\end{array}$ & $\begin{array}{l}\text { Emulsification } \\
\text { activity (\%) }\end{array}$ \\
\hline No nitrogen source & $0.52 \pm 0.10^{\mathrm{d}^{* *}}$ & $0^{\mathrm{d}^{* *}}$ & $0^{\mathrm{e}^{* *}}$ & $0^{\mathrm{d}^{* *}}$ \\
\hline$\left(\mathrm{NH}_{4}\right)_{2} \mathrm{SO}_{4}$ & $2.55 \pm 0.21^{\mathrm{c}}$ & $20.51 \pm 2.25^{\mathrm{c}}$ & $0.51 \pm 0.20^{\mathrm{d}}$ & $36.30 \pm 4.20^{\mathrm{b}}$ \\
\hline $\mathrm{NaNO}_{3}$ & $3.25 \pm 0.81^{\mathrm{b}}$ & $30.30 \pm 2.00^{\mathrm{a}}$ & $2.54 \pm 0.40^{\mathrm{a}}$ & $50.10 \pm 5.12^{\mathrm{a}}$ \\
\hline $\mathrm{NH}_{4} \mathrm{Cl}$ & $2.18 \pm 0.72^{\mathrm{c}}$ & $25.70 \pm 2.21^{\mathrm{b}}$ & $1.24 \pm 0.63^{\mathrm{b}}$ & $39.12 \pm 3.05^{\mathrm{b}}$ \\
\hline $\mathrm{NH}_{4} \mathrm{NO}_{3}$ & $2.52 \pm 0.88^{\mathrm{c}}$ & $23.10 \pm 3.71^{\mathrm{bc}}$ & $1.14 \pm 0.24^{\mathrm{b}}$ & $36.25 \pm 3.20^{\mathrm{b}}$ \\
\hline Beef extract & $3.92 \pm 0.60^{\mathrm{a}}$ & $15.50 \pm 2.57^{\mathrm{d}}$ & $0.89 \pm 0.18^{\mathrm{c}}$ & $24.16 \pm 4.55^{\mathrm{c}}$ \\
\hline Momosodium glutamate & $4.18 \pm 1.53^{\mathrm{a}}$ & $20.19 \pm 2.20^{\mathrm{c}}$ & $0.62 \pm 0.09^{\mathrm{d}}$ & $20.50 \pm 4.61^{c}$ \\
\hline Peptone & $4.09 \pm 0.85^{\mathrm{a}}$ & $26.34 \pm 3.51^{b}$ & $1.30 \pm 0.84^{\mathrm{b}}$ & $38.28 \pm 4.32^{\mathrm{b}}$ \\
\hline Yeast extract & $4.14 \pm 0.68^{\mathrm{a}}$ & $22.00 \pm 4.25^{\mathrm{bc}}$ & $0.65 \pm 0.15^{\mathrm{d}}$ & $22.60 \pm 2.30^{\mathrm{c}}$ \\
\hline
\end{tabular}

*Values are given as means \pm SD from triplicate determinations.

${ }^{* *}$ Different superscript letters in the same column indicate significant differences $(p<0.05)$.

Table 3 Effect of carbon to nitrogen $(\mathrm{C}: \mathrm{N})$ ratio on biosurfactant production by Pectinatus cerevisiiphilus $\mathrm{CT} 3$, which were cultivated in $250 \mathrm{ml}$ flask containing $50 \mathrm{ml} \mathrm{MSM}$ medium at $30{ }^{\circ} \mathrm{C}$ in a shaking incubator at $150 \mathrm{rpm}$ for $48 \mathrm{~h}$.

\begin{tabular}{|c|c|c|c|c|}
\hline$C: N$ & $\begin{array}{c}\text { Dry cell } \\
\text { weight }(\mathrm{g} / \mathrm{l})\end{array}$ & $\begin{array}{c}\text { Surface tension } \\
\text { reduction }(\mathrm{mN} / \mathrm{m})^{*}\end{array}$ & $\begin{array}{c}\begin{array}{c}\text { Biosurfactant } \\
(\mathrm{g} / \mathrm{l})^{*}\end{array} \\
\end{array}$ & $\begin{array}{c}\text { Emulsification } \\
\text { activity }^{*}(\%)\end{array}$ \\
\hline 1 & $1.81 \pm 0.09^{\mathrm{e}^{* *}}$ & $12.50 \pm 2.18^{\mathrm{e}^{* *}}$ & $0.93 \pm 0.21^{\mathrm{d}^{* *}}$ & $30.21 \pm 2.84^{\mathrm{d}^{* *}}$ \\
\hline 5 & $3.25 \pm 0.81^{\mathrm{c}}$ & $30.30 \pm 2.00^{\mathrm{d}}$ & $2.54 \pm 0.40^{\mathrm{c}}$ & $50.10 \pm 5.12^{\mathrm{c}}$ \\
\hline 10 & $3.52 \pm 1.03^{\mathrm{cd}}$ & $33.91 \pm 3.80^{\mathrm{cd}}$ & $2.62 \pm 0.29^{\mathrm{c}}$ & $55.42 \pm 4.36^{\mathrm{b}}$ \\
\hline 15 & $3.67 \pm 1.02^{\mathrm{bc}}$ & $35.02 \pm 4.12^{\mathrm{bc}}$ & $2.71 \pm 0.47^{\mathrm{bc}}$ & $56.11 \pm 5.21^{b}$ \\
\hline 20 & $3.89 \pm 1.01^{\mathrm{ab}}$ & $39.30 \pm 5.28^{\mathrm{a}}$ & $2.85 \pm 0.11^{\mathrm{ab}}$ & $57.65 \pm 4.64^{\mathrm{ab}}$ \\
\hline 25 & $4.01 \pm 0.74^{\mathrm{a}}$ & $42.15 \pm 4.61^{\mathrm{a}}$ & $2.94 \pm 0.20^{\mathrm{a}}$ & $59.20 \pm 3.52^{\mathrm{a}}$ \\
\hline 30 & $4.00 \pm 0.13^{\mathrm{a}}$ & $42.14 \pm 3.20^{\mathrm{a}}$ & $2.91 \pm 0.13^{\mathrm{a}}$ & $58.50 \pm 6.51^{\mathrm{a}}$ \\
\hline 35 & $3.74 \pm 1.25^{\mathrm{bc}}$ & $35.32 \pm 4.15^{\mathrm{bc}}$ & $2.58 \pm 1.11^{\mathrm{c}}$ & $55.81 \pm 5.20^{\mathrm{b}}$ \\
\hline
\end{tabular}

*Values are given as means \pm SD from triplicate determinations.

${ }^{* *}$ Different superscript letters in the same column indicate significant differences $(p<0.05)$. 


\section{Effect of inoculum concentration on growth and biosurfactant production by Pectinatus cerevisiiphilus CT3}

The effect of the inoculum concentrations on the growth and biosurfactant production of $P$. cerevisiiphilus CT3 cultivated in optimal medium $\left(25 \mathrm{~g} / 1\right.$ glucose and $\left.1 \mathrm{~g} / 1 \mathrm{NaNO}_{3}\right)$ is illustrated in Table 4. Cell growth of $P$. cerevisiiphilus CT3 increased when the inoculation concentration increased. Increasing the inoculum concentration from 2.0 to $5.0 \%(\mathrm{v} / \mathrm{v})$ resulted in a higher level of surface tension reduction $(19.5-42.15 \mathrm{mN} / \mathrm{m})$ and emulsification activity $(35.12-42.15 \%)$. However, further increase in inoculum concentration did not affect surface tension reduction and emulsification activity. These results were in accordance with [13], who reported that increasing the inoculum's size from 1.0 to 5.0 (v/v) resulted in an increase of biomass and biosurfactant yield from Selenomonas ruminantium CT2. However, an inoculum concentration of more than $5.0(\mathrm{v} / \mathrm{v})$ did not have a significant impact in enhancing the biosurfactant production.

Table 4 Effect of inoculum concentrations on biosurfactant production by Pectinatus cerevisiiphilus CT3, which were cultivated in $250 \mathrm{ml}$ flask containing $50 \mathrm{ml} \mathrm{MSM}$ medium at $30{ }^{\circ} \mathrm{C}$ in a shaking incubator at $150 \mathrm{rpm}$ for $48 \mathrm{~h}$.

\begin{tabular}{|c|c|c|c|c|}
\hline $\begin{array}{c}\text { Inoculum } \\
\text { concentration } \\
(\%, \mathrm{v} / \mathrm{v}) \\
\end{array}$ & $\begin{array}{c}\text { Dry cell } \\
\text { weight }(\mathrm{g} / \mathrm{l})\end{array}$ & $\begin{array}{l}\text { Surface tension } \\
\text { reduction }(\mathrm{mN} / \mathrm{m})\end{array}$ & $\begin{array}{c}\text { Biosurfactant } \\
(\mathrm{g} / \mathrm{l})^{*}\end{array}$ & $\begin{array}{l}\text { Emulsification } \\
\text { activity }^{*}(\%)\end{array}$ \\
\hline 2 & $2.18 \pm 0.95^{\mathrm{d}^{* *}}$ & $19.50 \pm 3.81^{\mathrm{d}^{* *}}$ & $1.95 \pm 0.18^{\mathrm{c}^{* *}}$ & $32.12 \pm 5.40^{\mathrm{d}^{* *}}$ \\
\hline 3 & $3.05 \pm 1.58^{\mathrm{c}}$ & $23.63 \pm 2.57^{\mathrm{c}}$ & $2.14 \pm 0.54^{\mathrm{c}}$ & $45.10 \pm 3.21^{\mathrm{c}}$ \\
\hline 4 & $3.51 \pm 1.03^{b}$ & $30.11 \pm 3.09^{b}$ & $2.52 \pm 0.98^{\mathrm{b}}$ & $50.21 \pm 4.36^{\mathrm{b}}$ \\
\hline 5 & $4.01 \pm 0.74^{\mathrm{a}}$ & $42.15 \pm 4.61^{\mathrm{a}}$ & $2.94 \pm 0.20^{\mathrm{a}}$ & $59.20 \pm 3.52^{\mathrm{a}}$ \\
\hline 6 & $4.09 \pm 1.84^{\mathrm{a}}$ & $42.30 \pm 4.81^{\mathrm{a}}$ & $2.85 \pm 0.63^{\mathrm{a}}$ & $59.51 \pm 5.41^{\mathrm{a}}$ \\
\hline 7 & $4.11 \pm 1.41^{\mathrm{a}}$ & $42.50 \pm 4.06^{\mathrm{a}}$ & $2.94 \pm 0.21^{\mathrm{a}}$ & $59.01 \pm 3.22^{\mathrm{a}}$ \\
\hline
\end{tabular}

${ }^{*}$ Values are given as means \pm SD from triplicate determinations.

${ }^{* *}$ Different superscript letters in the same column indicate significant differences $(p<0.05)$.

Time course of growth and biosurfactant production by Pectinatus cerevisiiphilus CT3

Time course studies were conducted on growth and biosurfactant production by $P$. cerevisiiphilus CT3 in MSM (pH 7.0) supplemented with $25 \mathrm{~g} / 1$ glucose and $1 \mathrm{~g} / 1 \mathrm{NaNO}_{3}$ as carbon and nitrogen sources, respectively. A $5 \%(\mathrm{v} / \mathrm{v})$ overnight inoculum concentration was incubated at $30{ }^{\circ} \mathrm{C}$ in a rotary shaker at $150 \mathrm{rpm}$ for $72 \mathrm{~h}$ (Figure 1). It was observed that this strain started to excrete biosurfactant after the lag phase, which was after $6 \mathrm{~h}$. of cultivation, as indicated by a decrease in the surface tension of the culture media. Under the studied conditions, the $\log$ phase occurred and ranged $9-48 \mathrm{~h}$. The surface tension of the culture medium was markedly reduced and it reached a minimum $(28.0 \mathrm{mN} / \mathrm{m})$ after $51 \mathrm{~h}$ of cultivation. However, the highest level of biosurfactant yield $(3.05 \mathrm{~g} / \mathrm{l})$ and emulsification activity $(60 \%)$ was obtained as the cultivation time approached $54 \mathrm{~h}$, which corresponded to the stationary phase of the microbial growth. Therefore, it can be concluded that the biosurfactant produced by $P$. cerevisiiphilus CT3 is a growth-associated production, or primary metabolite. In this case, there is a parallel relationship between the substrate utilization, growth, and biosurfactant production [33]. Growth-associated production of biosurfactant has been reported for Pseudomonas fluorescens Migula 1895-DSMZ [34], Selenomonas ruminantium CT2 [13], Deinococcus caeni PO5 and Halobacteriaceae archaeon AS65 [35]. From the results obtained, it can be seen that a cultivation time of $54 \mathrm{~h}$ can give the highest biosurfactant activity. 


\section{Recovery of biosurfactant}

Crude extract of biosurfactant was recovered from the culture supernatant of $P$. cerevisiiphilus CT3 by precipitation and extraction with several organic solvents. The highest yield $(5.45 \mathrm{~g} / \mathrm{ml})$ was obtained from acid precipitation; however, the CMC and surface tension at CMC of this method was high $(40 \mathrm{mg} / \mathrm{l}$ and $60 \mathrm{mN} / \mathrm{m}$, respectively) when compared with other recovery methods (Table 5). Normally, biosurfactants recovered by acid precipitation are high molecular-weight biosurfactants which tend to exhibit emulsification activity rather than the reduction of surface tension $[13,14]$. Among the six methods, chloroform:methanol was the most efficient in biosurfactant recovery with $3.05 \mathrm{~g} / \mathrm{l}, 10 \mathrm{mg} / \mathrm{l}$ and $28.0 \mathrm{mN} / \mathrm{m}$ for yield, $\mathrm{CMC}$ and surface tension at $\mathrm{CMC}$, respectively. It has also been previously reported that the extraction of biosurfactants consisting of hydrophilic and hydrophobic parts by a mixture of chloroform and methanol is highly efficient $[11,36]$. The efficiency of chloroform:methanol extraction may be a result of this solvent system containing both non-polar (chloroform, $\log \mathrm{P}=1.97$ ) and highly polar (methanol, $\log \mathrm{P}=-0.74$ ) solvents. Thus, it is more effective than the single solvent (ethyl acetate, $\log \mathrm{P}=0.73$ ) used. Chloroform:methanol extraction has been reported for biosurfactant recovery from Bacillus licheniformis TR7 and Bacillus subtilis SA9 [37], Leucobacter komagatae 183 [11] and Oleomonas sagaranensis AT18 [12].

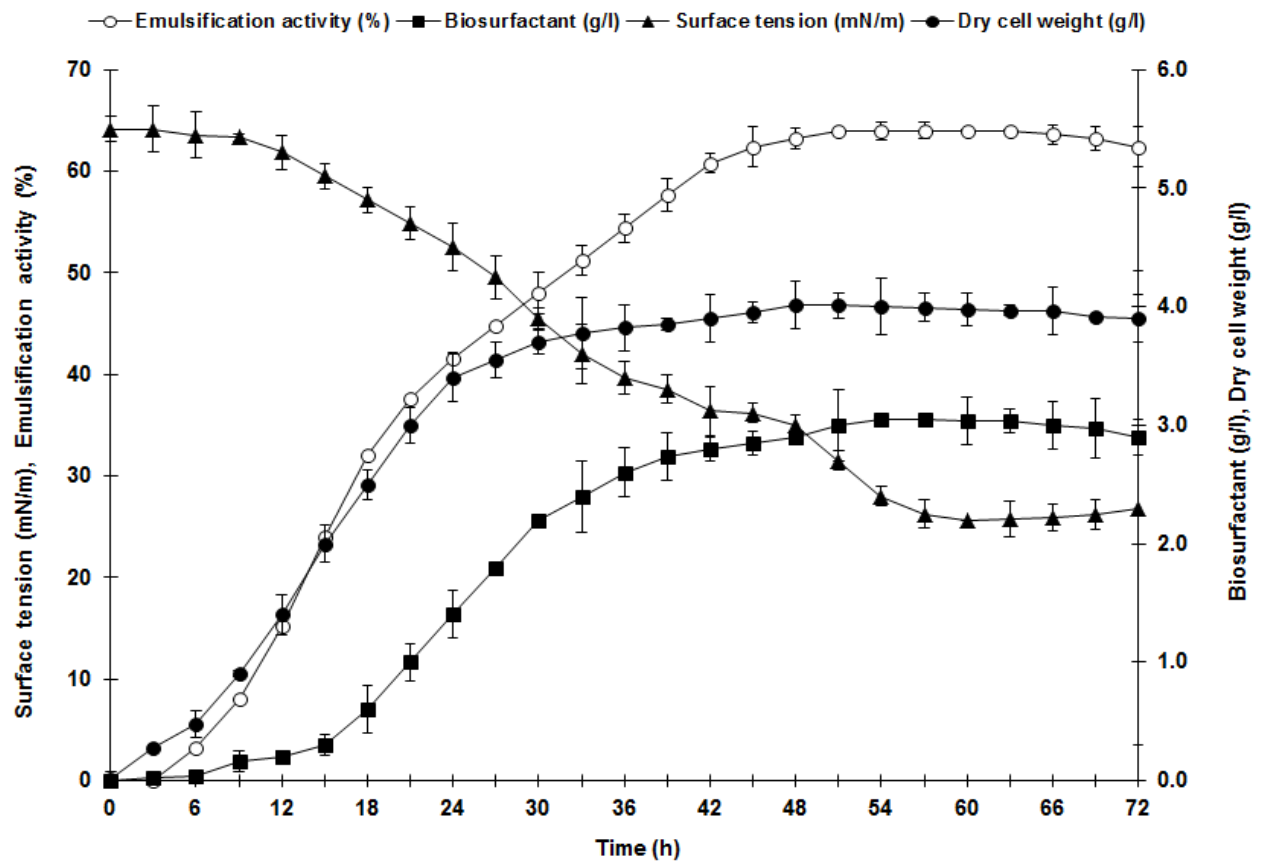

Figure 1 Time course of growth and biosurfactant production by Pectinatus cerevisiiphilus CT3 in optimal medium $\left(25 \mathrm{~g} / 1\right.$ glucose and $\left.1 \mathrm{~g} / 1 \mathrm{NaNO}_{3}\right)$ at $150 \mathrm{rpm}$ and $\left.30{ }^{\circ} \mathrm{C}\right)$. Bars indicate standard deviations from triplicate determinations. 
http://wjst.wu.ac.th

Table 5 Effect of extraction methods on yield and critical micelle concentration (CMC) of biosurfactant produced by Pectinatus cerevisiiphilus CT3.

\begin{tabular}{lccc}
\hline Recovery method & Yield $(\mathbf{g} / \mathbf{l})^{*}$ & $\begin{array}{c}\text { Critical micelle concentration } \\
(\mathbf{m g} / \mathbf{l})^{*}\end{array}$ & $\begin{array}{c}\text { Surface tension } \\
(\mathbf{m N} / \mathbf{m})^{*}\end{array}$ \\
\hline Acetone precipitation & $5.15 \pm 1.12^{\mathrm{b}^{* *}}$ & $35.00 \pm 0.00^{\mathrm{b**}}$ & $55.0 \pm 2.50^{\mathrm{b}^{* *}}$ \\
Acid precipitation & $5.45 \pm 1.87^{\mathrm{a}}$ & $40.00 \pm 0.00^{\mathrm{a}}$ & $60.0 \pm 5.00^{\mathrm{a}}$ \\
$\left.\mathrm{NH}_{4}\right)_{2} \mathrm{SO}_{4}$ precipitation & $5.02 \pm 0.54^{\mathrm{b}}$ & $20.00 \pm 0.00^{\mathrm{c}}$ & $42.5 \pm 4.50^{\mathrm{c}}$ \\
$\mathrm{CH}_{3} \mathrm{Cl}: \mathrm{MeOH}$ extraction & $3.05 \pm 0.42^{\mathrm{d}}$ & $10.00 \pm 0.00^{\mathrm{d}}$ & $28.0 \pm 3.50^{\mathrm{f}}$ \\
Ethanol precipitation & $3.71 \pm 0.35^{\mathrm{c}}$ & $20.00 \pm 0.00^{\mathrm{c}}$ & $30.5 \pm 4.50^{\mathrm{e}}$ \\
Ethyl acetate extraction & $3.25 \pm 0.47^{\mathrm{d}}$ & $20.00 \pm 0.00^{\mathrm{c}}$ & $35.5 \pm 3.50^{\mathrm{d}}$ \\
\hline
\end{tabular}

*Values are given as means \pm SD from triplicate determinations.

${ }^{* *}$ Different superscript letters in the same column indicate significant differences $(p<0.05)$.

\section{Surface tension and Critical Micelle Concentration (CMC) of the biosurfactant}

The surface tension of biosurfactant solution from $P$. cerevisiiphilus CT3 was measured as a function of concentration in order to compare the surface activities of excreted biosurfactant. A comparison of surface tension with biosurfactant concentration indicated that the surface tension of pure water rapidly decreased as the concentration of biosurfactant increased, and a minimum surface tension $(28.0 \mathrm{mN} / \mathrm{m})$ was observed (Figure 2). From the break point of the plotting of surface tension against biosurfactant concentration, the critical micelle concentration (CMC) was $10 \mathrm{mg} / \mathrm{l}$. The CMC is a key characteristic of a surfactant [2,3]. Before the CMC is reached, according to the concentration of surfactant, the surface tension significantly varies; however, the surface tension remains relatively unchanged after reaching the CMC [1,4]. Temperature, pressure, and the presence or concentration of other surface-active substances and electrolytes play important roles as controllers of the CMC value for a given dispersant in a given medium [8]. Micelles only show above critical micelle temperature [6,7]. Biosurfactant production from $P$. cerevisiiphilus $\mathrm{CT} 3$ showed a lower minimum surface tension and CMC value than that of biosurfactant from Bacillus subtilis $(29.0 \mathrm{mN} / \mathrm{m}, 40 \mathrm{mg} / \mathrm{l})$ [38], Rhodococcus sp. strain PML026 (29.0 mN/m, $250 \mathrm{mg} / \mathrm{l})$ [39], Bacillus subtilis LB5a (26.6 mN/m, 33.0 mg/l) [40], Bacillus subtilis PT2 (26.4 mN/m, $25.0 \mathrm{mg} / \mathrm{l})$ and Pseudomonas aeruginosa SP4 $(28.3 \mathrm{mN} / \mathrm{m}, 120 \mathrm{mg} / \mathrm{l})$ [41], Pseudomonas aeruginosa $\mathrm{S} 6(33.9 \mathrm{mN} / \mathrm{m}, 50 \mathrm{mg} / \mathrm{l})$ [42], Pseudomonas aeruginosa Bs20 $(29.5 \mathrm{mN} / \mathrm{m}$, $13.4 \mathrm{mg} / \mathrm{l})$ [43], and Lactobacillus paracasei (41.8 mN/m, $250 \mathrm{mg} / \mathrm{l})$ [44].

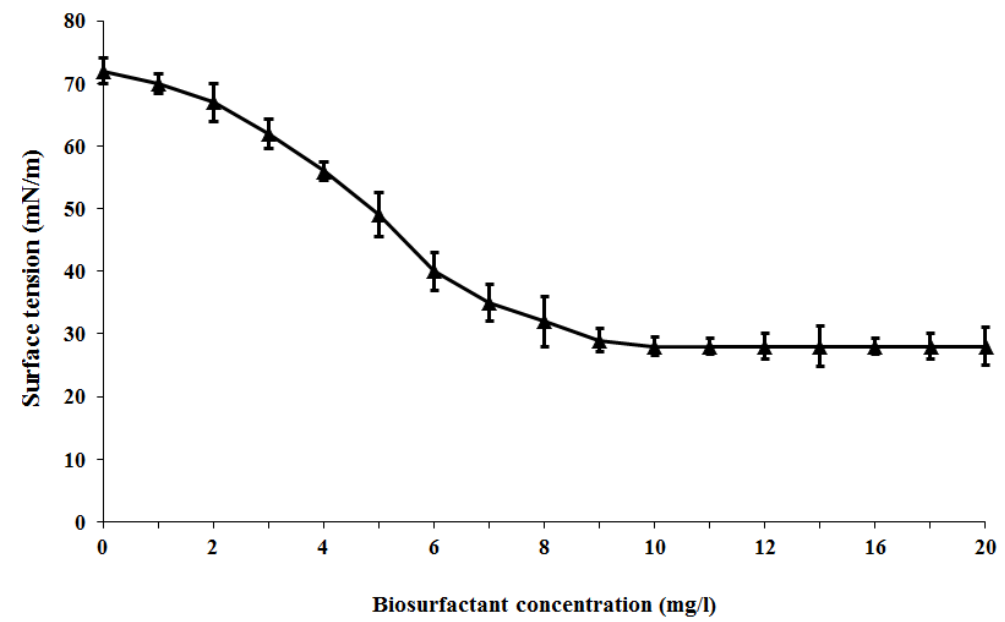

Figure 2 Surface tension vs biosurfactant concentration produced by Pectinatus cerevisiiphilus CT3. 
http://wjst.wu.ac.th

\section{Effect of temperature, $\mathrm{pH}$ and salinity on biosurfactant stability}

The results obtained from thermal stability analysis of biosurfactant over a wide range of temperatures $\left(4-121^{\circ} \mathrm{C}\right)$ revealed that the biosurfactant from P. cerevisiiphilus $\mathrm{CT} 3$ was thermostable (Figure 3). Heating of the biosurfactant solution up to $100^{\circ} \mathrm{C}$ (or its autoclaving at $121{ }^{\circ} \mathrm{C}$ ) caused little effect on emulsification capacity and surface tension activity. An approximately $15 \%$ reduction in emulsification activity $\left(\mathrm{E}_{24}\right)$ and surface tension was observed after autoclaving at $121{ }^{\circ} \mathrm{C}$ for $20 \mathrm{~min}$. The surface tension reduction and $\mathrm{E}_{24}$ were relatively stable at such temperatures $\left(\mathrm{ST} \approx 29 \mathrm{mN} / \mathrm{m}, \mathrm{E}_{24} \approx 57\right)$.

Figure 4 shows the effect of $\mathrm{pH}$ on the biosurfactant stability. The emulsification ability and surface activity of the obtained biosurfactant remained relatively stable for $\mathrm{pH}$ changes between $\mathrm{pH} 6$ and 11, showing higher stability for alkaline conditions than acidic conditions. At $\mathrm{pH} 12$, the $\mathrm{E}_{24}$ and surface tension values were $57 \%$ and $32 \mathrm{mN} / \mathrm{m}$, respectively. However, at $\mathrm{pH} 5, \mathrm{E}_{24}$ decreased to $40 \%$ and surface tension increased to $45 \mathrm{mN} / \mathrm{m}$. In addition, for $\mathrm{pH}$ values lower than 4 , the samples become turbid, due to partial precipitation of the biosurfactant. The optimum $\mathrm{pH}$ for both parameters, namely biosurfactant activity $(\mathrm{ST}=28 \mathrm{mN} / \mathrm{m})$ and emulsification capacity $\left(\mathrm{E}_{24}=60\right)$, was determined to be $6-7$.

Figure 5 demonstrates the effect of $\mathrm{NaCl}$ on the surface tension and $\mathrm{E}_{24}$ of obtained biosurfactant. As shown in Figure 5, negligible changes were observed in the surface activity for an increase in the $\mathrm{NaCl}$ concentration up to $12 \%$. Likewise, an increase in $\mathrm{NaCl}$ concentration up to $15 \%$ did not significantly affect $\mathrm{E}_{24}$. However, both $\mathrm{E}_{24}$ and surface activity were affected at $\mathrm{NaCl}$ concentrations higher than $15 \%$, with $\mathrm{E}_{24}$ decreasing to less than $50 \%$ and surface activity increasing to more than $35 \mathrm{mN} / \mathrm{m}$.

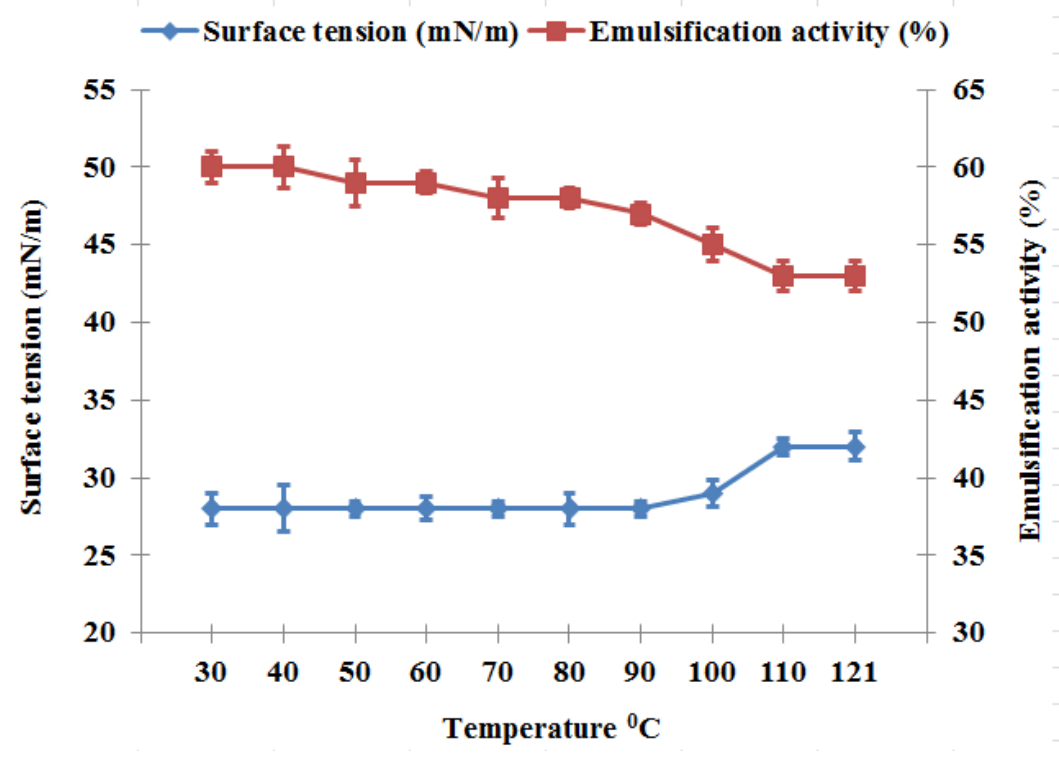

Figure 3 Effect of temperature on activity of biosurfactant produced by Pectinatus cerevisiiphilus CT3. Bars represent the standard deviation from three determinations. 


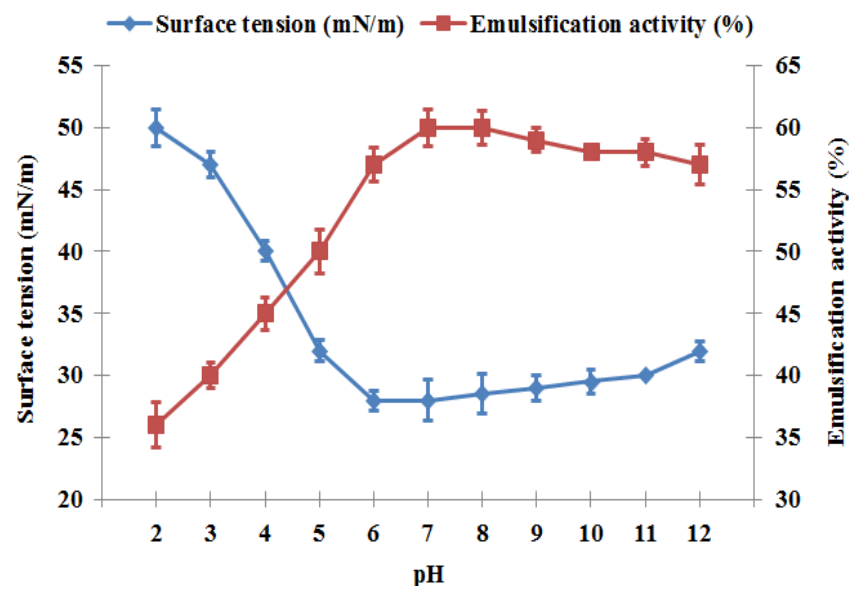

Figure 4 Effect of $\mathrm{pH}$ on activity of biosurfactant produced by Pectinatus cerevisiiphilus CT3. Bars represent the standard deviation from three determinations.

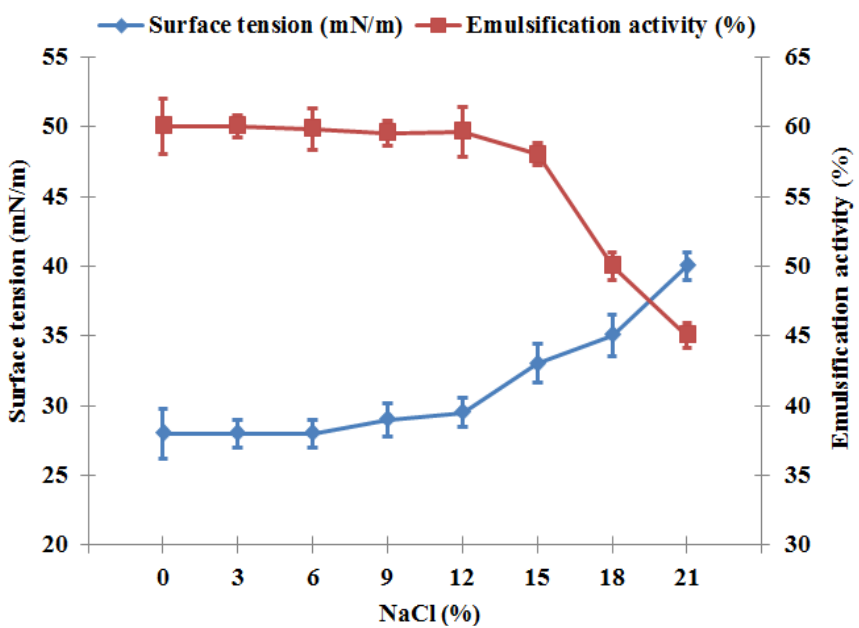

Figure 5 Effect of $\mathrm{NaCl}$ concentration on activity of biosurfactant produced by Pectinatus cerevisiiphilus CT3. Bars represent the standard deviation from three determinations.

\section{Biosurfactant Characteristics}

The chemical nature of biosurfactant from $P$. cerevisiiphilus CT3 was observed as a single spot on TLC. This fraction showed a positive reaction with ninhydrin reagent and iodine vapor, indicating the presence of peptide and lipid moieties in the molecule (data not shown). The biochemical composition of the biosurfactant revealed that it is a mixture of proteins and lipids in a combination of 69 and $25 \%$, respectively. These results indicated the existence of lipopeptide biosurfactant. The lipopeptide nature of the biosurfactant was further confirmed by FT-IR spectra of the compound (Figure 6). The IR spectrum in $\mathrm{KBr}$ showed bands characteristic of peptides at 3,432-3,306 $\mathrm{cm}^{-1}$ (NH stretching mode). At $1,654 \mathrm{~cm}^{-}$ ${ }^{1}$, the stretching mode of a CO-N bond was observed, and at $1,552 \mathrm{~cm}^{-1}$, a deformation mode of the $\mathrm{NH}$ bond combined with an NH stretching mode occurred. The presence of an aliphatic chain was indicated by the $\mathrm{CH}$ stretching modes at 2,958 -2,854 and 1,464 $-1,022 \mathrm{~cm}^{-1}$. These results strongly indicate that the biosurfactant contains aliphatic and peptide-like moieties. The biosurfactant composition contains more aliphatic than peptide-like moieties, making it preferable for use as a hydrophobic solvent rather than in a hydrophilic solution $[45,46]$. 




Figure 6 Fourier transform infrared spectrum of biosurfactant produced by Pectinatus cerevisiiphilus CT3.

\section{Antibacterial activity of biosurfactant}

The antibacterial activity of biosurfactant from $P$. cerevisiiphilus CT3 is shown in Tables 6 and Figure 7. Biosurfactant from $P$. cerevisiiphilus CT3 was found to have antimicrobial activity against several strains of the tested bacteria. The biosurfactant showed inhibitory activity against Gram-positive bacteria $B$. cereus and $S$. aureus and Gram-negative bacteria E. coli, S. Thyphi, V. vulnifus and $V$. choleare. The highest concentration tested $(200 \mathrm{mg} / \mathrm{ml})$, biosurfactant from $P$. cerevisiiphilus CT3 was active against all tested bacterial strains. The antimicrobial activity against Gram-positive bacteria was lower than the activity against Gram-negative bacteria. The biosurfactant was able to inhibit $B$. cereus and $S$. aureus in concentrations as low as $25 \mathrm{mg} / \mathrm{ml}$. However, the MIC values for most of the tested Gram-negative bacteria (E. coli, S. thyphi, V. vulnifus and V. choleare) were $50 \mathrm{mg} / \mathrm{ml}$. High MIC-values correlating with higher resistance were often seen when Gram-negative microorganisms were tested [47]. Gram-negative bacteria have been reported to be more resistant to external substances [48]. This higher level of resistance has been attributed to the presence of lipopolysaccharides in their outer membranes, making them naturally resistant to certain antibacterial agents [49]. On the other hand, Gram-positive organisms that were tested showed higher sensitivity towards the biosurfactant than the Gram-negative bacteria. The reason could be attributed to the differences between their cell wall compositions. Grampositive bacteria contain an outer peptidoglycan layer, which is an infective permeability barrier [50]. 
http://wjst.wu.ac.th

Table 6 Antimicrobial activity of biosurfactant produced by Pectinatus cerevisiiphilus CT3 by agar well diffusion method against bacteria and fungi.

\begin{tabular}{|c|c|c|c|c|c|}
\hline \multirow{2}{*}{ Microorganisms } & \multicolumn{5}{|c|}{ Antimicrobial zone diameter $(\mathrm{mm})$ at concentration $(\mathrm{mg} / \mathrm{ml}){ }^{*}$} \\
\hline & 200 & 100 & 50 & 25 & 12.5 \\
\hline \multicolumn{6}{|l|}{ Gram-positive bacteria } \\
\hline Bacillus cereus & $20.23 \pm 3.21^{\mathrm{ab} * *}$ & $18.53 \pm 3.06^{\mathrm{a} \mathrm{b}^{* *}}$ & $11.17 \pm 4.15^{\mathrm{b}^{* *}}$ & $7.94 \pm 2.01^{\mathrm{b}^{* *}}$ & 0 \\
\hline Staphylococcus aureus & $18.27 \pm 4.25^{\mathrm{bc}}$ & $16.93 \pm 6.15^{\mathrm{bc}}$ & $10.57 \pm 3.12^{\mathrm{bc}}$ & $6.06 \pm 2.15^{\mathrm{b}}$ & 0 \\
\hline \multicolumn{6}{|l|}{ Gram-negative bacteria } \\
\hline Escherichia coli & $12.11 \pm 2.10^{\mathrm{d}}$ & $8.53 \pm 1.06^{\mathrm{ef}}$ & $7.57 \pm 2.11^{\mathrm{de}}$ & 0 & 0 \\
\hline Salmonella Thyphi & $10.14 \pm 2.15^{\mathrm{d}}$ & $7.27 \pm 2.15^{\mathrm{ef}}$ & $6.23 \pm 1.05^{\mathrm{de}}$ & 0 & 0 \\
\hline Vibrio vulnificus & $20.48 \pm 4.10^{\mathrm{ab}}$ & $18.13 \pm 2.06^{\mathrm{ab}}$ & $10.97 \pm 3.12^{\mathrm{bc}}$ & 0 & 0 \\
\hline Vibrio cholerae & $12.37 \pm 1.15^{\mathrm{d}}$ & $8.27 \pm 1.06^{\mathrm{ef}}$ & $7.03 \pm 2.15^{\mathrm{de}}$ & 0 & 0 \\
\hline \multicolumn{6}{|l|}{ Fungi } \\
\hline Aspergillus niger & $18.01 \pm 5.54^{\mathrm{bc}}$ & $15.52 \pm 7.21^{\mathrm{bc}}$ & $12.23 \pm 3.25^{\mathrm{b}}$ & $6.03 \pm 2.12^{\mathrm{b}}$ & 0 \\
\hline Aspergillus oryzae & $16.86 \pm 5.29^{c}$ & $12.97 \pm 4.54^{\mathrm{d}}$ & $10.4 \pm 4.87^{\mathrm{bc}}$ & $8.13 \pm 2.42^{\mathrm{ab}}$ & 0 \\
\hline Candida albicans & $12.64 \pm 2.02^{\mathrm{d}}$ & $10.52 \pm 2.03^{\mathrm{de}}$ & $8.01 \pm 2.53^{\mathrm{cd}}$ & $6.59 \pm 1.02^{\mathrm{b}}$ & 0 \\
\hline Mucor sp. & $22.43 \pm 4.12^{\mathrm{a}}$ & $19.43 \pm 1.37^{\mathrm{a}}$ & $15.05 \pm 2.84^{\mathrm{a}}$ & $9.59 \pm 1.02^{\mathrm{a}}$ & 0 \\
\hline Penicillium sp. & $9.04 \pm 2.17^{\mathrm{d}}$ & $6.73 \pm 4.32^{\mathrm{f}}$ & 0 & 0 & 0 \\
\hline Phytophthora palmivora & $20.38 \pm 3.62^{\mathrm{ab}}$ & $17.51 \pm 2.80^{\mathrm{abc}}$ & $12.66 \pm 1.09^{\mathrm{b}}$ & $8.03 \pm 2.51^{\mathrm{ab}}$ & 0 \\
\hline Rhizopus oryzae & $10.81 \pm 2.21^{\mathrm{d}}$ & $8.80 \pm 3.60^{\mathrm{ef}}$ & $5.81 \pm 2.20^{\mathrm{e}}$ & $4.87 \pm 1.21^{\mathrm{c}}$ & 0 \\
\hline
\end{tabular}

*Values are given as means \pm SD from triplicate determinations.

${ }^{* *}$ Different superscript letters in the same column indicate significant differences $(p<0.05)$.

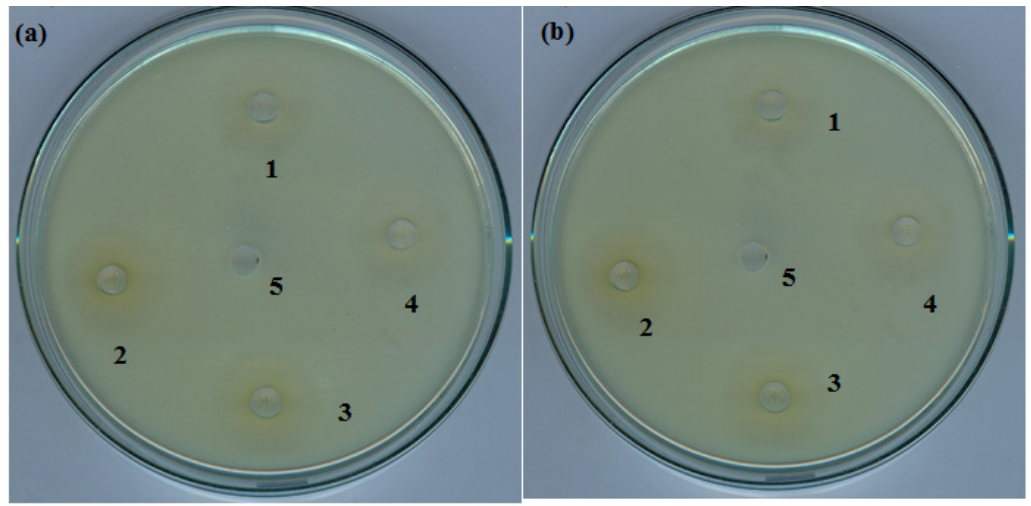

Figure 7 Antibacterial activity of biosurfactant from Pectinatus cerevisiiphilus CT3 against Bacillus cereus (a) and Staphylococcus aureus (b). Numbers $1-4$ denote $25 \mathrm{mg} / \mathrm{ml}$ of biosurfactant dissolved in distilled water. Distilled water (5) was used as a control.

\section{Antifungal activity of biosurfactant}

The results of antifungal activity testing of biosurfactant from marine isolated P. cerevisiiphilus CT3 are given in Table 6. At the highest tested concentration, the obtained biosurfactant was active against all seven tested fungal strains. The highest inhibition was found for Mucor sp. followed by Phytophthora palmivora, Aspergillus niger Aspergillus oryzae, Candida albicans, Rhizopus oryzae and Penicillium sp., respectively. Figure 8 shows the antifungal activity of the biosurfactant from isolated $P$. 
http://wjst.wu.ac.th

cerevisiiphilus CT3 against Mucor sp. and P. palmivora. Several biosurfactants are known to contain peptides with antibiotic properties against bacteria, fungi and yeasts [3]. However, this is the first report describing the antimicrobial activity of biosurfactant obtained from genus Pectinatus.
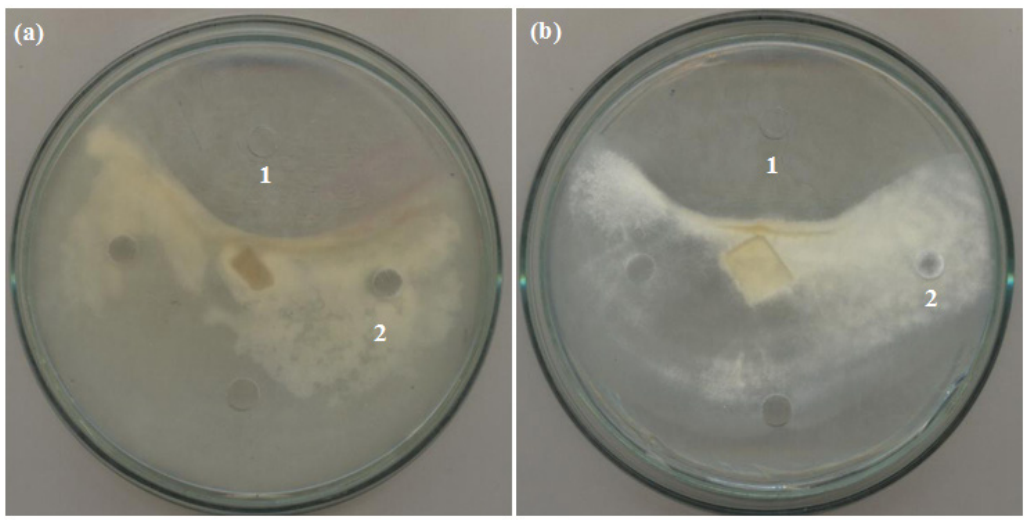

Figure 8 Antifungal activity of biosurfactant from Pectinatus cerevisiiphilus CT3 against Mucor sp. (a) and Phytophthora palmivora (b) after incubation in Sabouraud Dextrose Agar for 7 days. Number 1 denotes $25 \mathrm{mg} / \mathrm{ml}$ of biosurfactant dissolved in distilled water. Distilled water (2) was used as a control.

\section{Conclusions}

This study examined the optimization for biosurfactant production by $P$. cerevisiiphilus CT3. The growth characteristics were obtained, and the properties of the biosurfactant were studied for indications of its possible industrial application. The potential of this biosurfactant for industrial uses was examined by studying its physical properties, i.e., the surface tension, CMC and emulsification activity. The chemical characterization of the biosurfactant obtained from FT-IR spectroscopy revealed the presence of lipopeptide in the molecules. The properties of the biosurfactant that were obtained indicate its suitability as an alternative to synthetic medicines and antimicrobial agents, indicating that it may be used as a safe and effective therapeutic agent.

\section{Acknowledgements}

We are grateful to Rajamangala University of Technology Srivijaya, Trang Campus for providing a scholarship for this research. We would like to thank Prince of Songkla University and the Office of the Higher Education Commission, Thailand, for their support of this work. We also thank Daniel Guiney for his assistance with the English text.

\section{Reference}

[1] JD Desai and IM Banat. Microbial production of surfactants and their commercial potential. Microbiol. Mol. Biol. Rev. 1997; 61, 47-64.

[2] AM Abdel-Mawgoud, F Lepine and E Deziel. Rhamnolipids: Diversity of structures, microbial origins and roles. Appl. Microbiol. Biotechnol. 2010; 86, 1323-36.

[3] IM Banat, A Franzetti, I Gandolfi, G Bestetti, MG Martinotti, L Fracchia, TJ Smyth and R Marchant. Microbial biosurfactants production, applications and future potential. Appl. Microbiol. Biotechnol. 2010; 87, 427-44.

[4] LR Rodrigues and JA Teixeira. Biomedical and therapeutic applications of biosurfactants. $A d v$. Exp. Med. Biol. 2010; 672, 75-87. 
http://wjst.wu.ac.th

[5] G Seydlová and J Svobodová. Review of surfactin chemical properties and the potential biomedical applications. Cent. Eur. J. Med. 2008; 3, 123-33.

[6] I Mnif and D Ghribi. Review lipopeptides biosurfactants: Mean classes and new insights for industrial, biomedical, and environmental applications. Biopolymers 2015; 104, 129-47.

[7] SK Satpute, GR Kulkarni, AG Banpurkar, IM Banat, NS Mone, RH Patil and SS Cameotra. Biosurfactant/s from Lactobacilli species: Properties, challenges and potential biomedical applications. J. Basic. Microb. 2016; 56, 1140-58.

[8] M Nitschke and SS Silva. Recent food applications of microbial surfactants. Crit. Rev. Food. Sci. 2018; 58, 631-8.

[9] EJ Gudiña, JA Teixeira and LR Rodrigues. Biosurfactants produced by marine microorganisms with therapeutic applications. Mar. Drugs 2016; 14, 38.

[10] A Saimmai, O Rukadee, T Onlamool, V Sobhon and S Maneerat. Characterization and phylogenetic analysis of microbial surface active compounds producing bacteria. Appl. Biochem. Biotechnol. 2012; 168, 1003-18.

[11] A Saimmai, V Sobhon and S Maneerat. Production of biosurfactant from a new and promising strain of Leucobacter komagatae 183. Ann. Microbiol. 2012; 62, 391-402.

[12] A Saimmai, O Rukadee, T Onlamool, V Sobhon and S Maneerat. Isolation and functional characterization of a biosurfactant produced by a new and promising strain of Oleomonassagaranensis AT18. World J. Microbiol. Biotechnol. 2012; 28, 2973-86.

[13] A Saimmai, T Onlamool, V Sobhon and S Maneerat. An efficient biosurfactant-producing bacterium Selenomonas ruminantium CT2, isolated from mangrove sediment in south of Thailand. World J. Microbiol. Biotechnol. 2013; 29, 87-102.

[14] A Saimmai, S Udomsilp and S Maneerat. Production and characterization of biosurfactant from marine bacterium of Inquilinus limosus KB3 grown on low-cost raw materials. Ann. Microbiol. 63, 1327-39.

[15] M Dubois, KA Gilles, JK Hamilton, PA Rebers and F Smith. Colorimetric method for determination of sugars and related substances. Anal. Chem. 1956; 28, 350-6.

[16] OH Lowry, NJ Rosebrough, AL Farr and RJ Randall. Protein measurement with the Folin phenol reagent. J. Biol. Chem. 1951; 193, 265-75.

[17] JM Folch, M Lees and HS Stanly. A simple method for the isolation and quantification of total lipids from animal tissues. J. Biol. Chem. 1956; 226, 497-509.

[18] P Das, S Mukherjee and R Sen. Substrate dependent production of extracellular biosurfactant by a marine bacterium. Bioresource Technol. 2009; 100, 1015-19.

[19] A Saimmai, V Sobhon and S Maneerat. Molasses a whole medium for biosurfactants production by Bacillus strains and their application. Appl. Biochem. Biotechnol. 2011; 165, 315-35.

[20] F Candan, M Unlu, B Tepe, D Daferera, M Polissiou, A Sokmen and HA Akpulat. Antioxidant and antimicrobial activity of the essential oil and methanol extracts of Achillea millefolium subsp. Millefolium Afan. (Asteraceae). J. Ethnopharmacol. 2003; 87, 215-20.

[21] JY Wu, KL Yeh, WB Lu, CL Lin and JS Chang. Rhamnolipid production with indigenous Pseudomonas aeruginosa EM1 isolated from oil-contaminated site. Bioresource Technol. 2008; 99, 1157-64.

[22] SH Kim, EJ Lim, SO Lee, JD Lee and TH Lee. Purification and characterization of biosurfactants from Nocardia sp. L-417. Biotechnol. Appl. Biochem. 2000; 31, 249-53.

[23] AS Monteiroa, TT Mirandaa, I Lulab, AML Denadaic, RD Sinisterra, MM Santoroe and VL Santosa. Inhibition of Candida albicans CC biofilms formation in polystyrene plate surfaces by biosurfactant produced by Trichosporon montevideense CLOA72. Colloid Surface B 2011; 84, 46776.

[24] HS Jeong, DJ Lim, SH Hwang, SD Ha and JY Kong. Rhamnolipid production by Pseudomonas aeruginosa immobilized in polyvinyl alcohol beads. Biotechnol. Lett. 2004; 26, 35-9. 
http://wjst.wu.ac.th

[25] YH Wei, CL Chou and JS Chang. Rhamnolipid production by indigenous Pseudomonas aeruginosa J4 originating from petrochemical wastewater. J. Biochem. Eng. 2005; 27, 146-54.

[26] NF Khairuddin, TETZ Mulok, KA Khalil, WSAW Omar and SH Saleh. Screening of Medium with Different range of Waste Frying Oil (WFO), Sodium Nitrate (NaNO3) and Sodium Chloride (NaCl) for Biosurfactant Production by Thermophilic Anoxybacillus sp. using Fractional Factorial Design (FFD). In: M Yusoff, N Hamid, M Arshad, A Arshad, A Ridzuan and H Awang. (Eds.). Springer, Singapore, 2015.

[27] C Dejwatthanakomol, J Anuntagool, M Morikawa and J Thaniyavarn. Production of biosurfactant by Wickerhamomyces anomalus PY189 and its application in lemongrass oil encapsulation. Sci. Asia 2016; 42, 252-8.

[28] AK Yadav, S Manna, K Pandiyan, A Singh, M Kumar, H Chakdar, PL Kashyap and AK Srivastava. Isolation and characterization of biosurfactant producing Bacillus sp. from diesel fuel-contaminated site. Microbiology 2016; 85, 56-62.

[29] AM Elazzazy, TS Abdelmoneim and OA Almaghrabi. Isolation and characterization of biosurfactant production under extreme environmental conditions by alkali-halo-thermophilic bacteria from Saudi Arabia. Saudi. J. Biol. Sci. 2015; 22, 466-75.

[30] AS Santos, AP Sampaio, GS Vasquez, LMS Anna, N Pereira and DM Freire. Evaluation of different carbon and nitrogen sources in the production of rhamnolipids by a strain of Pseudomonas. Appl. Biochem. Biotechnol. 2002; 98, 1025-35.

[31] M Benincasa, J Contiero, MA Manresa and IO Moraes. Rhamnolipid production by Pseudomonas aeruginosa LBI growing on soapstock as the sole carbon source. J. Food. Eng. 200; 254, 283-8.

[32] HS Kim, JW Jeon, BH Kim, CY Ahn, HM Oh and BD Yoon. Extracellular production of a glycolipid biosurfactant, mannosylerythritol lipid, by Candida sp. SY16 using fed-batch fermentation. Appl. Microbiol. Biotechnol. 2006; 70, 391-6.

[33] L Rodrigues, J Teixeira, R Oliveira and HC der Mei. Response surface optimization of the medium components for the production of biosurfactants by probiotic bacteria. Process. Biochem. 2006; 41, $1-10$.

[34] M Abouseoud, R Maachi, A Amrane, S Boudergua and A Nabi. Evaluation of different carbon and nitrogen sources in production of biosurfactant by Pseudomonas fluorescens. Desalination 2008; 223, 143-51.

[35] CC Chooklin, S Maneerat and A Saimmai. Utilization of banana peel as a novel substrate for biosurfactant production by Halobacteriaceaearchaeon AS65. Appl. Biochem. Biotechnol. 2014; 173, 624-45.

[36] MS Kuyukina, IB Ivshina, SO Makarov, LV Litvinenko, CJ Cunningham and JC Philip. Effect of biosurfactants on crude oil desorption and mobilization in a soil system. Environ. Int. 2005; 31, 155 61 .

[37] A Saimmai, V Sobhon and S Maneerat. Molasses as a whole medium for biosurfactants production by Bacillus strains and their application. Appl. Biochem. Biotechnol. 2011; 165, 315-35.

[38] DA Vaz, EJ Gudina, EJ Alameda, JA Teixeira and LR Rodrigues. Performance of a biosurfactant produced by a Bacillus subtilis strain isolated from crude oil samples as compared to commercial chemical surfactants. Colloid Surf. B 2012; 89, 167-74.

[39] DA White, LC Hirda and ST Ali. Production and characterization of a trehalolipid biosurfactant produced by the novel marine bacterium Rhodococcus sp., strain PML026. J. Appl. Microbiol. 2013; 115, 744-55.

[40] M Nitschke and G Pastore. Production and properties of a surfactant obtained from Bacillus subtilis grown on cassava wastewater. Bioresource. Technol. 2006; 97, 336-41.

[41] O Pornsunthorntawee, P Wongpanit, S Chavadej, M Abe and R Rujiravanit. Structural and physicochemical characterization of crude biosurfactant produced by Pseudomonas aeruginosa SP4 isolated from petroleum-contaminated soil. Bioresource. Technol. 2008; 99, 1589-95. 
http://wjst.wu.ac.th

[42] H Yin, J Qiang, Y Jia, J Ye, H Peng, H Qin, N Zhang and B He. Characteristics of biosurfactant produced by Pseudomonas aeruginosa S6 isolated from oil-containing wastewater. Process Biochem. 2009; 44, 302-8.

[43] AM Abdel-Mawgoud, MM Aboulwafa and NAH Hassouna. Characterization of rhamnolipid produced by Pseudomonas aeruginosa isolate Bs20. Appl. Biochem. Biotechnol. 2009; 157, 329-45.

[44] EJ Gudina, JA Teixeira and LR Rodrigues. Isolation and functional characterization of a biosurfactant produced by Lactobacillus paracasei. Colloid. Surf. B 2011; 76, 298-304.

[45] JF Liu, SM Mbadinga, SZ Yang, JD Gu and BZ Mu. Chemical Structure, property and potential applications of biosurfactants produced by Bacillus subtilis in petroleum recovery and spill mitigation. Int. J. Mol. Sci. 2015; 16, 4814-37.

[46] K Patowary, R Patowary, MC Kalita and S Deka. Characterization of biosurfactant produced during degradation of hydrocarbons using crude oil as sole source of carbon. Front. Microbiol. 2017; 8, 279.

[47] R Tepsorn. 2009, Antimicrobial Activity of Thai Traditional Medicinal Plants Extract Incorporated Alginate-tapioca Starch based Edible Films against Food Related Bacteria Including Foodborne Pathogens. Ph. D. Dissertation, University of Hohenheim, Germany.

[48] PS Negi, AS Chauhan, GA Sadia, YS Rohinishree and RS Ramteke. Antioxidant and antimicrobial activities of various seabuckthorn (Hippophaer hamnoides L.) seed extracts. Food. Chem. 2005; 92 , 119-24.

[49] H Nikaido and M Vaara. Molecular basis of bacterial outer membrane permeability. Microbiol. Rev. $1985 ; 49,1-32$.

[50] R Scherrer and P Gerhardt. Molecular sieving by the Bacillus megaterium cell wall and protoplast. J. Bacteriol. 1971; 107, 718-35. 